اثر ضربه قطرات باران بر ويزگىهاى هيدروليكى جريان شيارى تحت تأثير درجه شيب

نسرين صادقيان' و عليرضا واعظى '” و ابوالفضل مجنونى هريس

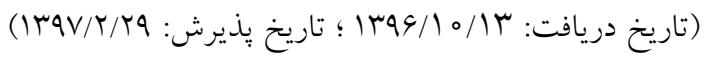

جكيده

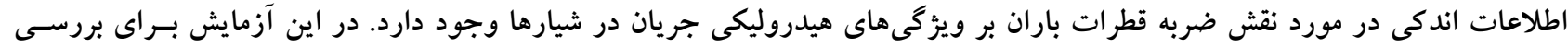

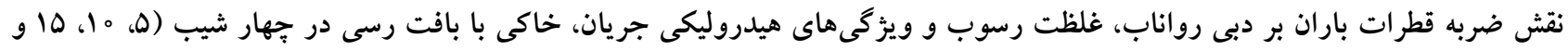

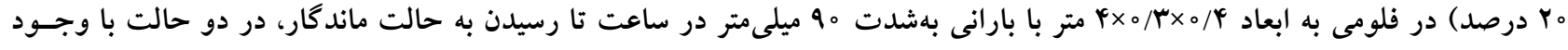

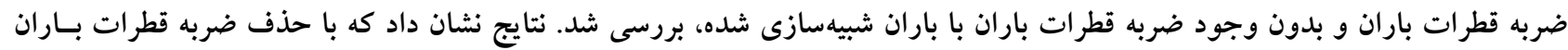

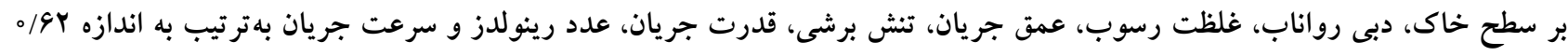

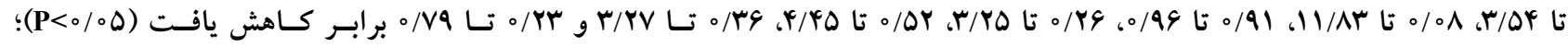

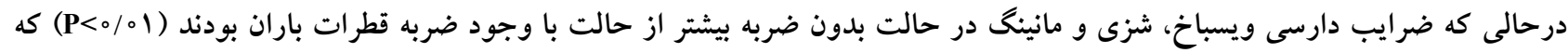

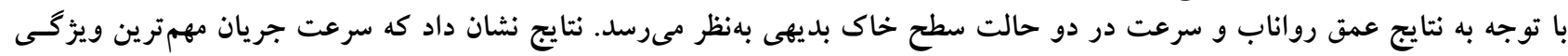

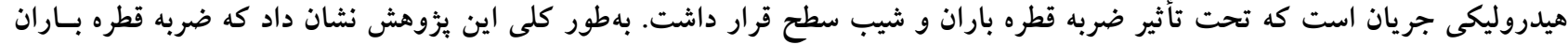

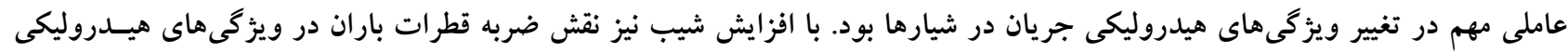

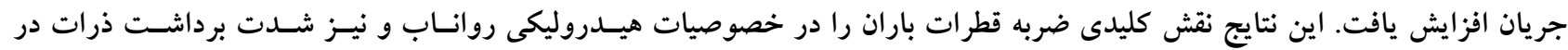

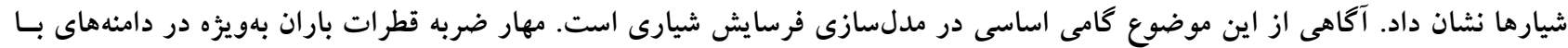

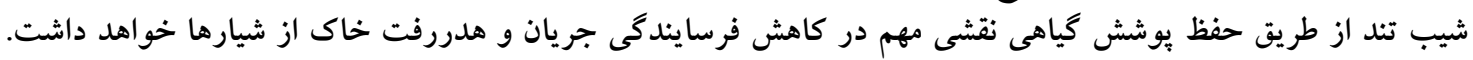

وازمهاى كليدى: تنش برشى، دبى رواناب، سطح خاك، غلظت رواناب و قدرت جريان

1. كروه علوم خاى، دانشكده كشاورزى، دانشكاه زنجان، زنجان r- كروه مهندسى آب دانشكده كشاورزى، دانشخاه تبريز

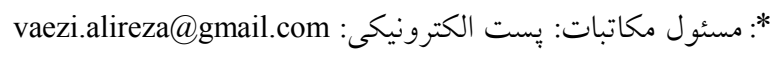


هستند و شكل ظاهرى آنها در مقياس زمانى كوتاه تغيير مى كند.

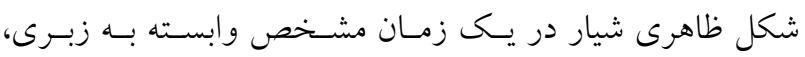

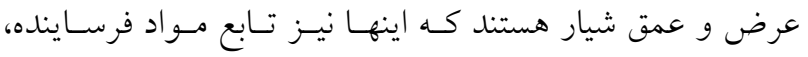

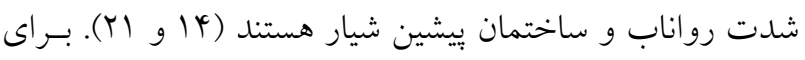

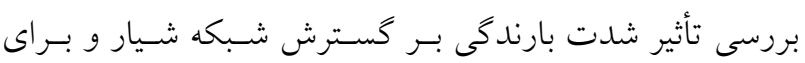
نشان دادن شاخصهايى براى توصيف كمى مورفولوزى شيارها،

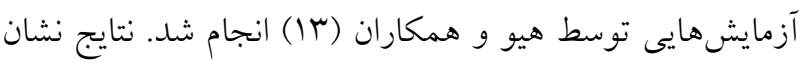

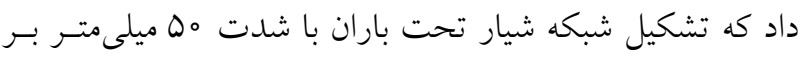
ساعت يبجيدهتر از بارش ه ه إيلى متر بر ساعت است. جرا كـه. باران شديدتر منجر به افت سريعتر نفوذيذيرى خـاك و ظهـور

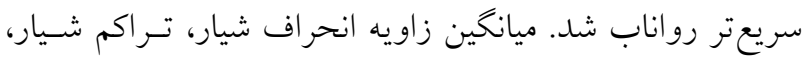

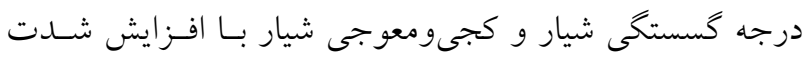

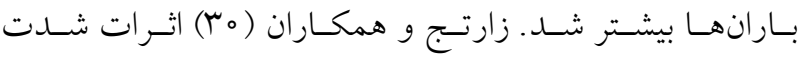

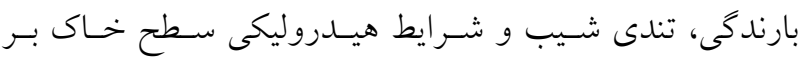

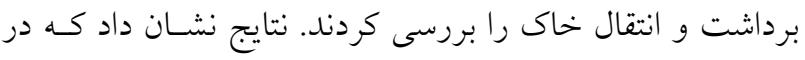

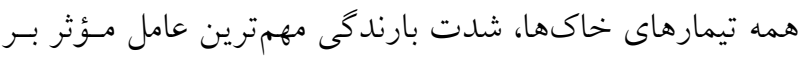

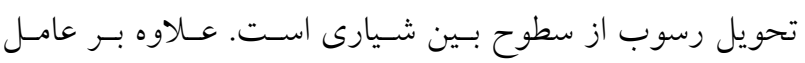

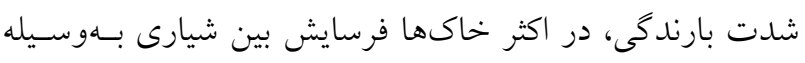

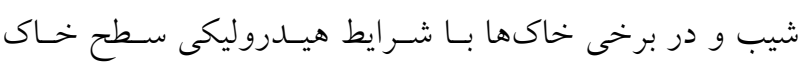

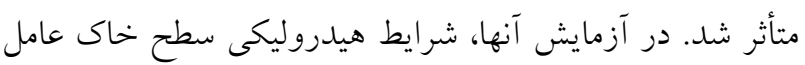

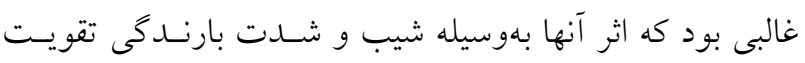

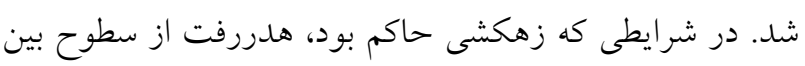

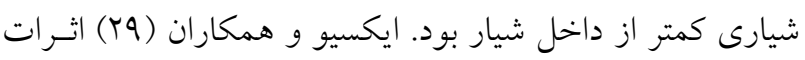

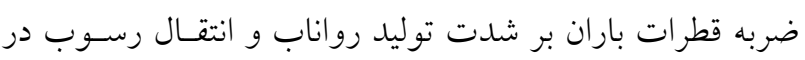

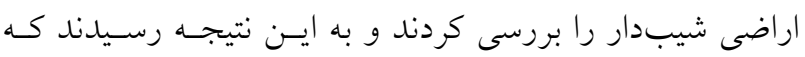

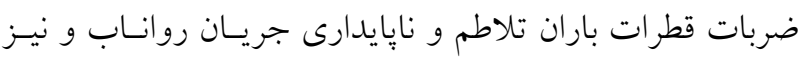

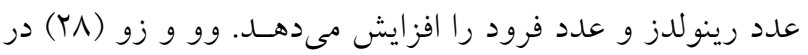

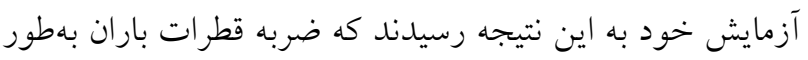

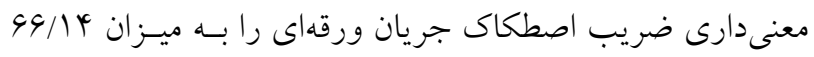

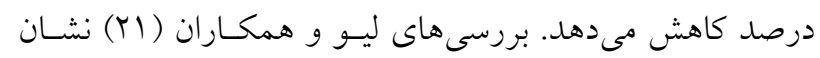
داد كه ضربه قطرات باران نقش كليدى در فرسايش و هدررفت خاى در اراضى شيبدار دارد؛ بهطورى كه هـدررفت خـاك در

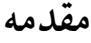

فرسايش خاك در طول بارندكى شامل فرايند بِيجيــــه برداشـت

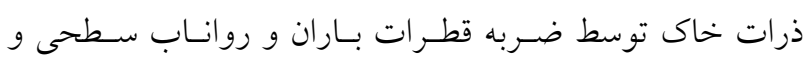

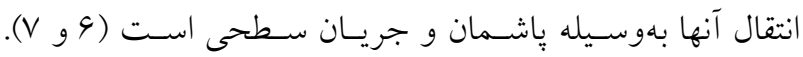

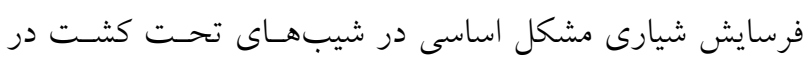

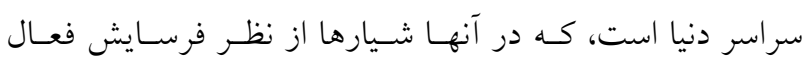
هستند. فرايندهاى فرسايش شيارى شامل برداشت ذرات، انتقال،

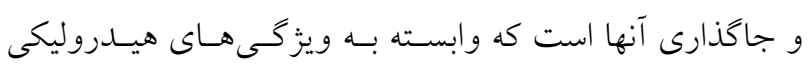

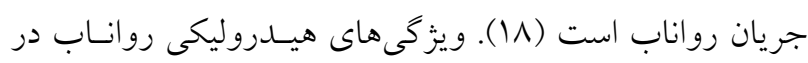

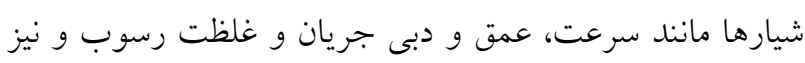

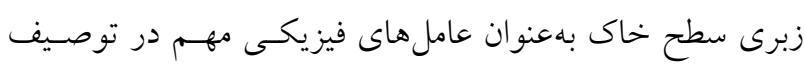

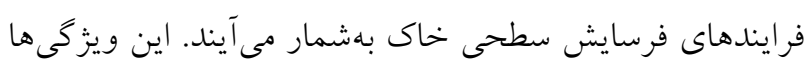

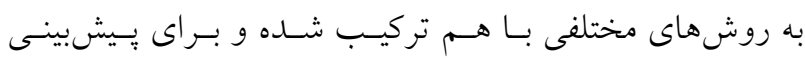

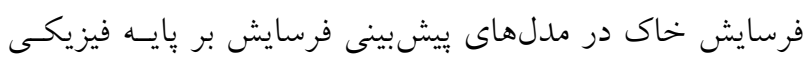

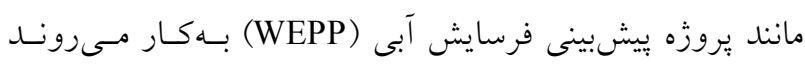

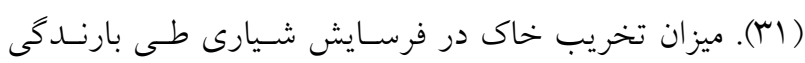

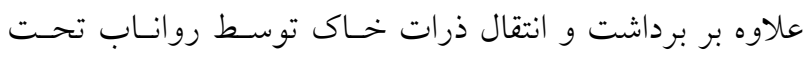
تأثير ضربه قطرات باران نيز است. قطرات بــاران نيـروى اوليـهـ

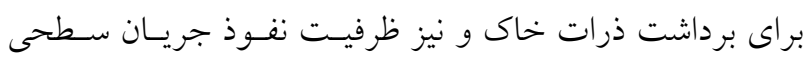

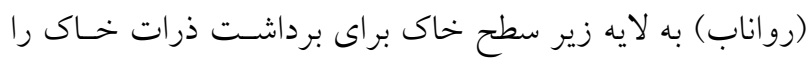

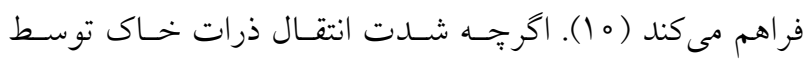

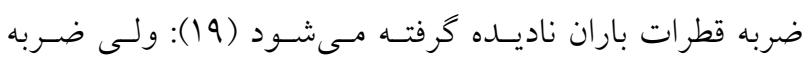

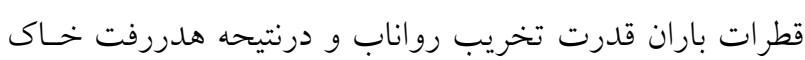

را افزايش مى دهد (ه)

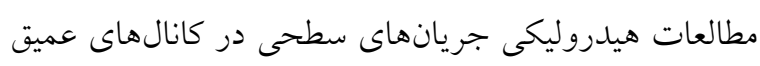

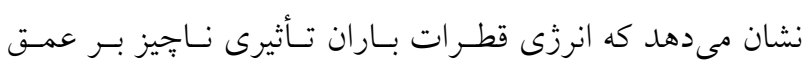

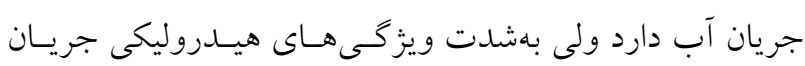

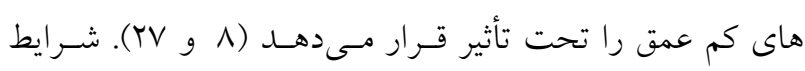

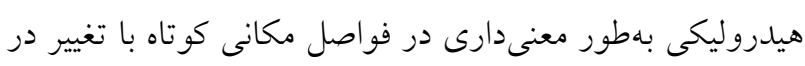
عمق جريان يا تغيير سطح بستر در طول جريان يا در زمين بـين

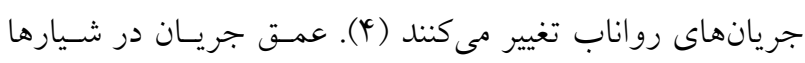

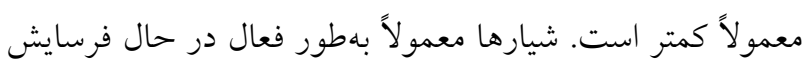




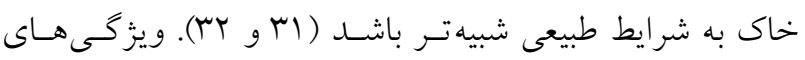

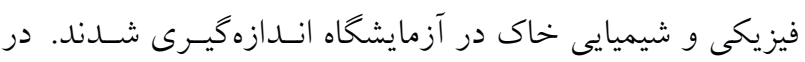

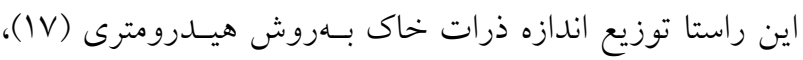

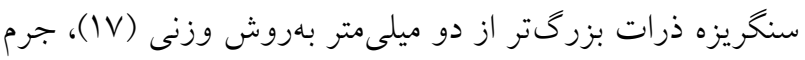

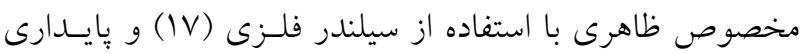

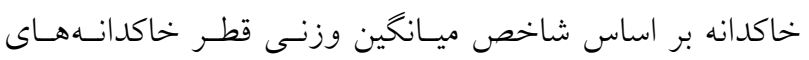
بايدار در روش الك تر (9) به مدت يك دقيقه در خاكدانههاى

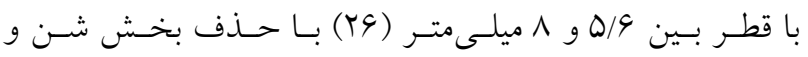
سنخريزه اندازهيرى شد.

شبيهسازى بارش، تعيين ويزگىهـاى هيـدروليكى جريـان و غلظت رسوب

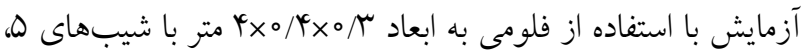

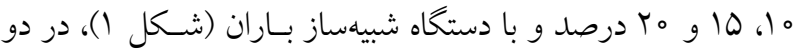
حالت با و بلدون وجود ضربه قطـرات بـاران انجـام گرفـت. مقــار خاك لازم براى فلوم بر مبناى جّالى ظاهرى نمونـه طبيعى خـاك

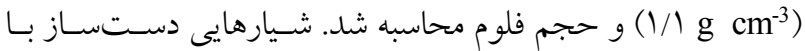
ايجاد جوى و يشته متوالى با عرض حسـود / / و عمـق هـ/ متـر

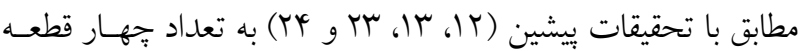

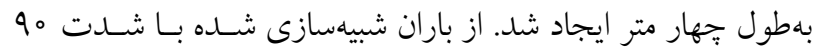

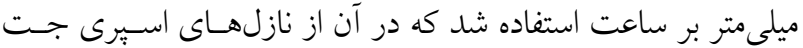
تحت فشار كه به فاصله مY سانتى متر از هم قـرار داشـتند، اسـتفاده

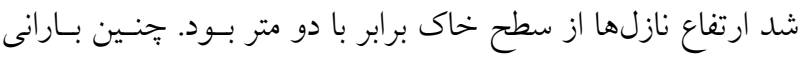

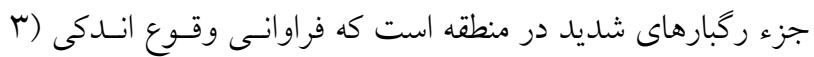

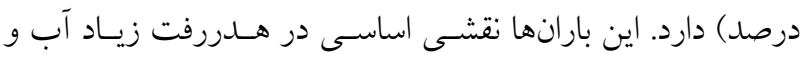
خاك طى سال در دامنههاى تحــت فرسـايش شـيارى دارنـــ (Y).

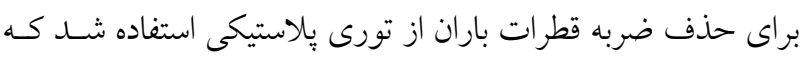

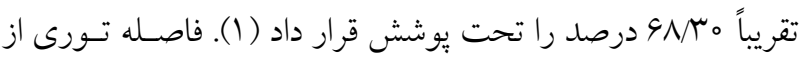

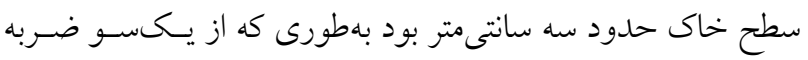

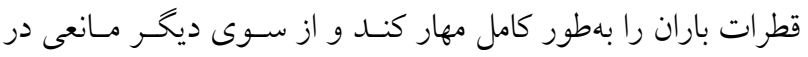
حركت جريان سطحى روى خاك ايجاد نكند. در هر رخــداد بـاران

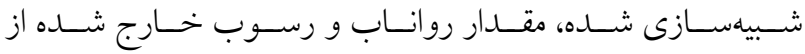

شرايط وجـود ضـربه قطـرات بـاران 19/1-19/4 برابـر بيشـتر از

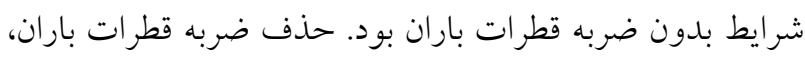

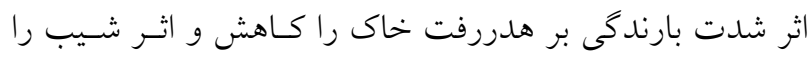

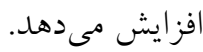

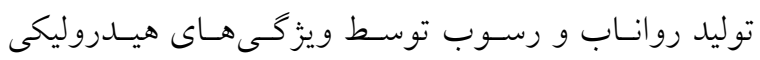

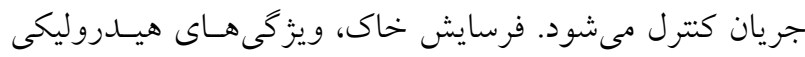

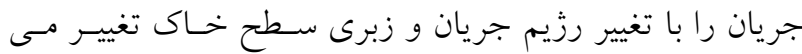
دهد؛ بدين ترتيب كه ضربات قطرات بـاران، غلظـت و تحويـل رسوب را افزايش مىدهد و درنتيجه باعـث تغييـر ويزگكى هـاى هيدروليكى جريان مىشود. از اينرو بررسى اثر ضـربه قطرات باران بر ويزگى هاى هيدروليكى جريان بـراى فهـم بهتـر فراينـــ فرسايش ضرورى است. بهطور كلى، بررسى منابع نشان مىدهد كه تحقيقات انجام شده در مـورد ويزگكى هـاى هيـدروليكى در شرايط مزرعهاى تحت تأثير جريانهاى با دبى ورودى متفـاوت، درون شيارهاى دستساز بوده است. در مطالعات اندكى كـه در

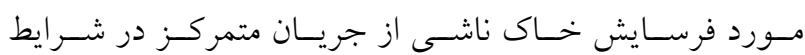

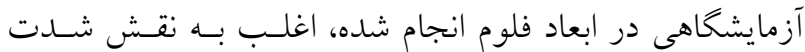

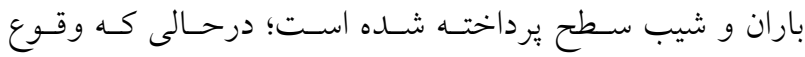
فرسايش شيارى در شيارها در شر ايط طبيعى عـلاوه بـر شـــت فئس

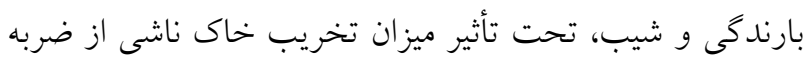

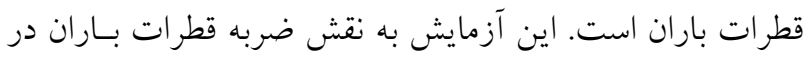

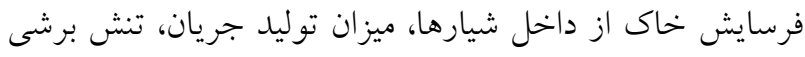

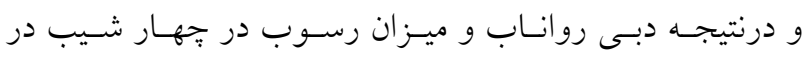

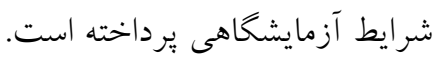

\section{مواد و روشها - ماد} نمونهبردارى و اندازهيرى ويزٔى هاى خاى

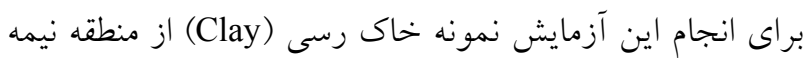

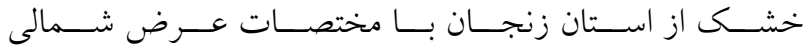

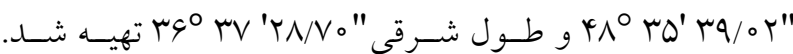

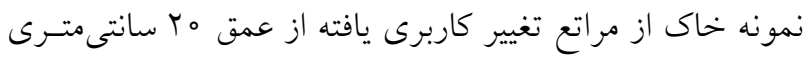

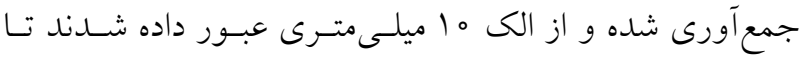




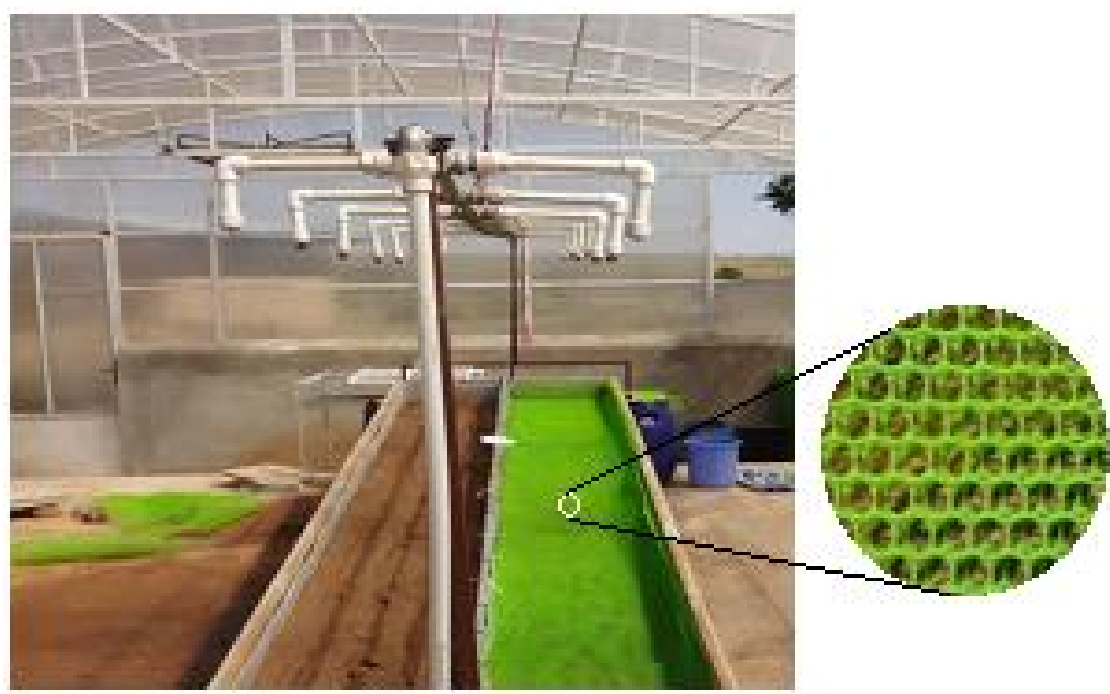

شكل ا. نمايى از فلوم و شبيهساز باران مورد استفاده در آزمايش در دو حالت با و بدون وجود ضربه قطرات باران

كه در آن g برابر شتاب ثقلى (m s (m S S برابر بـا متوسط شـيب

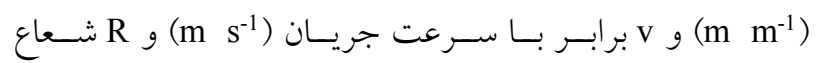

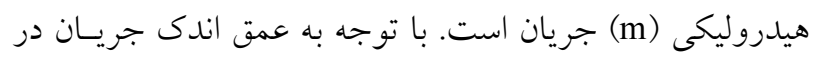

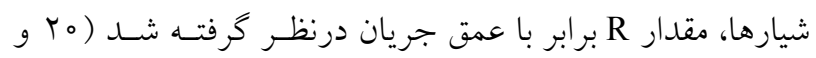

ضريب زبرى مانينگ بهصورت زير محاسبه شد (11): $\mathrm{n}=\frac{\mathrm{R}^{\frac{2}{3}} \mathrm{~s}^{\frac{1}{2}}}{\mathrm{~V}^{2}}$

ضريب زبرى شزى نيز از رابطه زير محاسبه شد (1): $\mathrm{C}=\frac{\mathrm{V}}{\frac{1}{\frac{1}{2}}}$ $\mathrm{RS}^{\frac{1}{2}}$

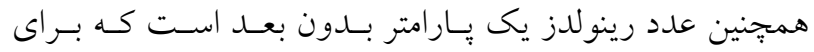

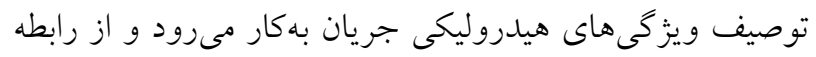

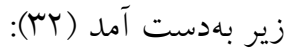
$\mathrm{R}_{\mathrm{n}}=\frac{\mathrm{VR}}{\mathrm{u}}$

كه در آن: لا ويسكوزيته دينـاميكى (m²s حرارت آب محاسبه مىشود.

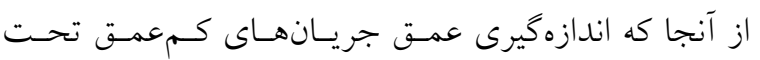

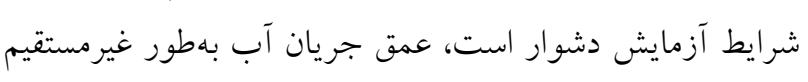
با استفاده از معادله زير تعيين شد (rr):
فلوم بهطور بيوسته در فواصل زمانى مختلـف (از بـازه زمـانى

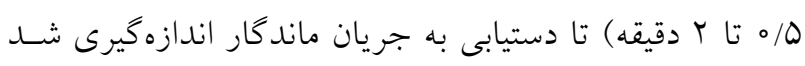

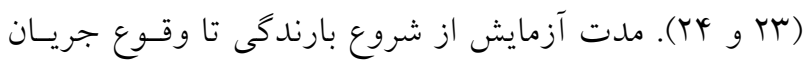

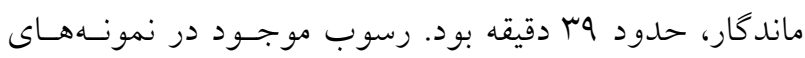

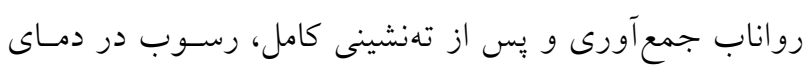

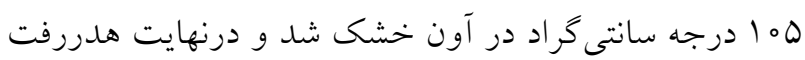

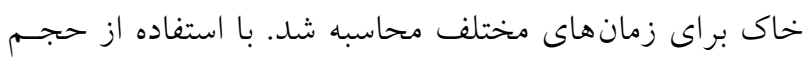

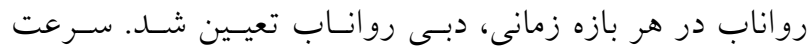

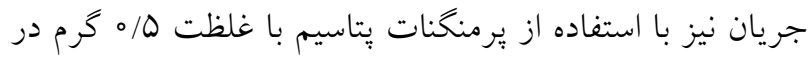

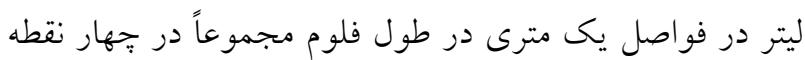

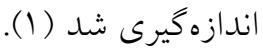

\section{تعيين ويزگ هاى هيدروليكى جريان}

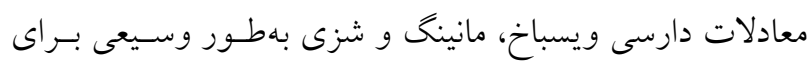

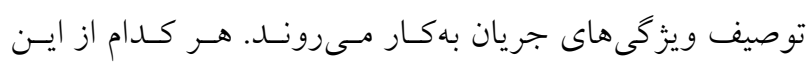

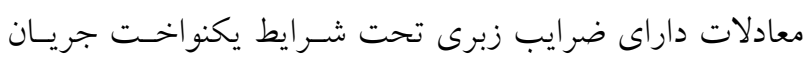

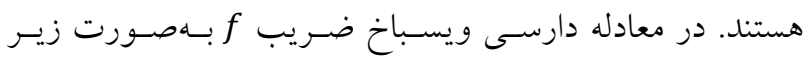

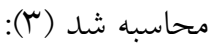
$\mathrm{f}=\frac{\mathrm{gRS}}{\mathrm{V}^{2}}$ 


\begin{tabular}{|c|c|}
\hline 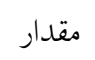 & ويز كى \\
\hline $1 V / 0$ & شن (.) \\
\hline r。 & سيلت (.) \\
\hline$\Delta Y / D$ & رس (.) \\
\hline$Y / V Y$ & سنخريزه (\%) \\
\hline $1 / 01$ & ميانخين وزنى قطر خاكدانههاى بايدار (mm) \\
\hline $1 / 1$ & جرم مخصوص ظاهرى ( ${ }^{-3} \mathrm{~g} \mathrm{~cm}^{-3}$ \\
\hline$\circ / N$ & 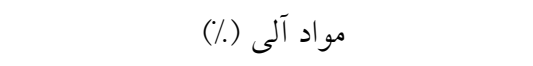 \\
\hline$T V / D \circ$ & كربنات كلسيم معادل (.٪) \\
\hline
\end{tabular}

قطر خاكدانههاى پيايدار در آب براى مدت يكى دقيقه، 1/01 ميلى متر بود كه نشان از ضعف مقاومت خاكدانههـا در برابـر

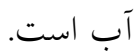

نقش ضربه قطرات بارن بر تغييرات دبسى روانــاب و غلظــت رسوب

رواناب ايجاد شده توسط ضربه قطرات باران در هر جهار شيب

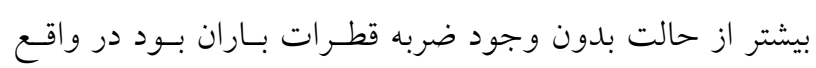

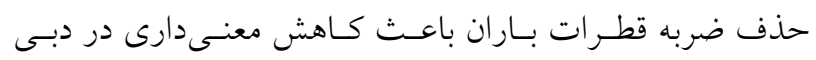
رواناب شد ( (P<0/01) (شكل r). با افزايش شيب در دو حالـت شرايط سطح خاى (با وجود ضربه و بدون وجود ضربه قطرات باران) دبى رواناب افزايش يافت ولى ميزان افزايش دبى رواناب

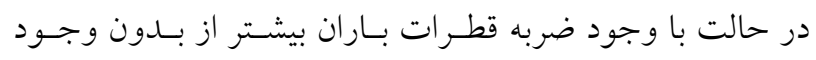
ضربه قطرات باران بود. ميزان كاهش دبى رواناب در شيبهـاى بالا در حالت بدون وجود ضربه بيشتر بود كـه ايسن امـر ممكـن

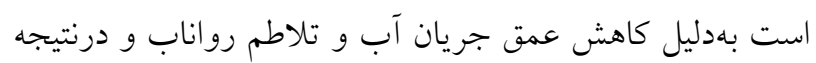

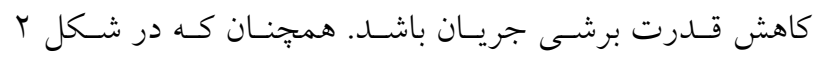
مشاهده مىشود غلظت رسـوب در تيمـار بــون وجـود ضـربه قطرات بار ان بهطور معنىدارى كمتر از حالت بـا وجــود ضـربه
$\mathrm{h}=\frac{\mathrm{Q}}{\mathrm{BV}}$

كه در آن: Q دبى جريـان درون شـيار (m²s

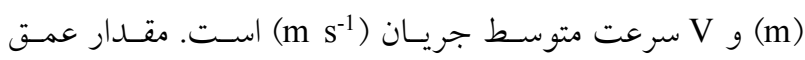
جريان براى جهار شيار درون فلوم جداكانه تعيين و ميانخين آن براى كل فلوم محاسبه شد. براى محاسبه تنش برشى از رابطه زير استفاده شد (YT):

$\tau=\rho_{\mathrm{f}} \mathrm{gRS}$

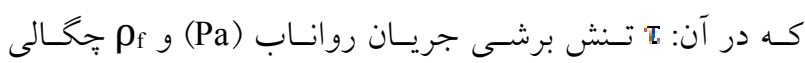
سيال) (kgm قدرت جريان نيز با استفاده از از رابطه زيــر بـهـ دسـت آمـــ

$\omega=\tau \mathrm{V}$

كه در آن: $\omega$ قدرت جريان با واحد kg mت است.

تجزيه و تحليل دادهها

تحليل آمارى مربوط به تفاوت بين شيبها از نظر ويزخىهــــ هيدروليكى جريان در دو حالت با وجود ضربه قطرات بـاران و بلدون وجود ضربه قطرات باران بهصـورت فاكتوريـل در قالـب

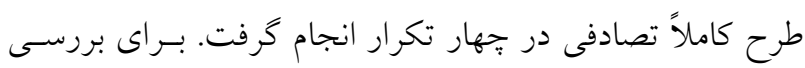
نرمال بودن دادهها از آزمون شاييرو ويلـى (TO) و بــراى انجـام مقايسه ميانخين عامل هاى آزمايش از آزمون دانكن استفاده شـــ.

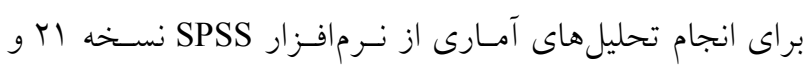
براى رسم نمودارها از نرمافزار Excel استفاده شد.

\section{نتايج و بحث} ويزگ گهاى خاى مورد بررسى

ويزّكىهاى فيزيكى و شيميايى خاك مورد بررسى در جـدول آورده شده است. خاى مورد بررسى داراى بافـت رسى (Clay) و مقدار اندى ماده آلى (س/ه درصد) است. با توجه به محتواى بالاى كربنات كلسيم در خاى (بيش از مب درصد)، خاكهـا در

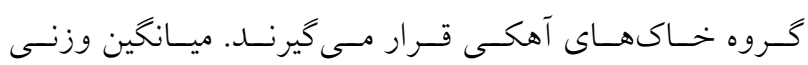



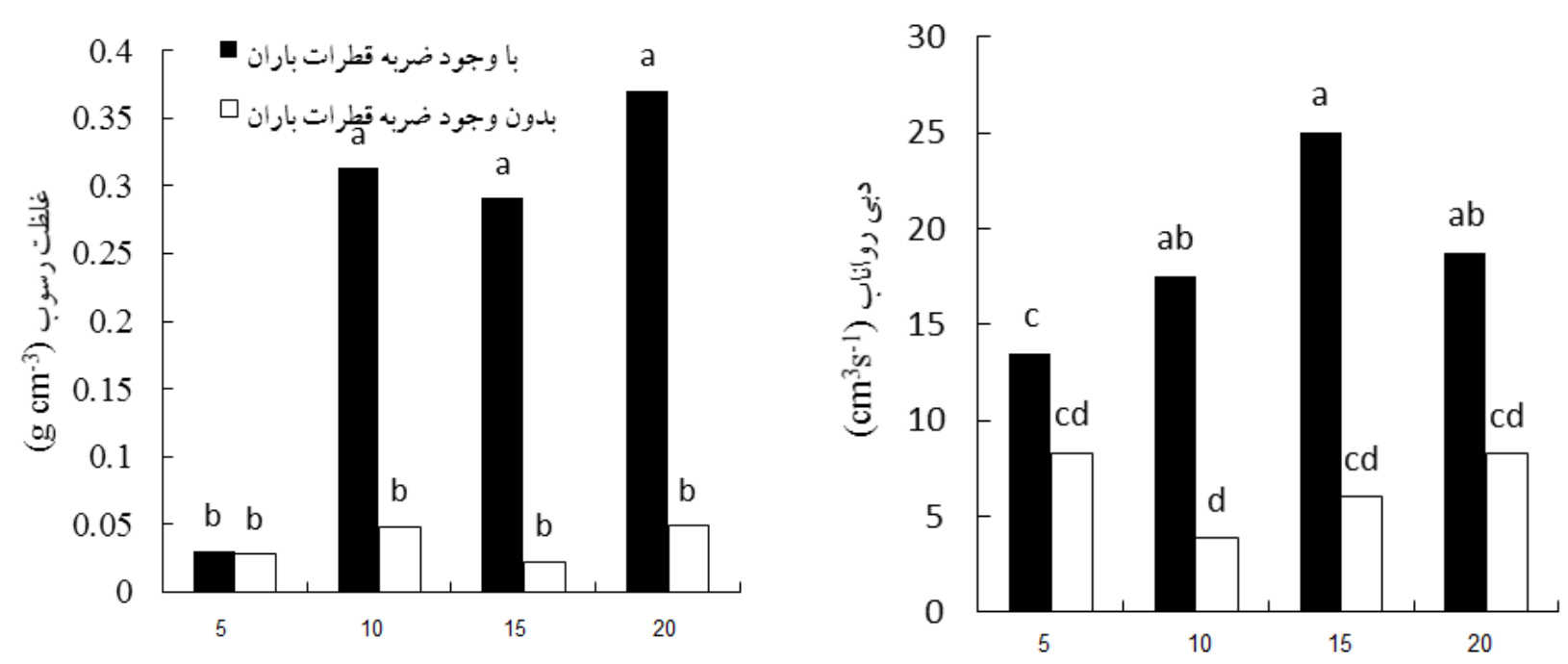

شبي () (1)

شتب (\%)

شكل r. مقايسه دبى رواناب و غلظت رسوب در دوحالت با وجود ضربه قطرات باران و بدون وجود ضربه قطرات باران در شيبهاى مورد مطالعه (حروف مشابه داراى اختلاف معنى دارى در سطح احتمال يكى درصد نيستند).

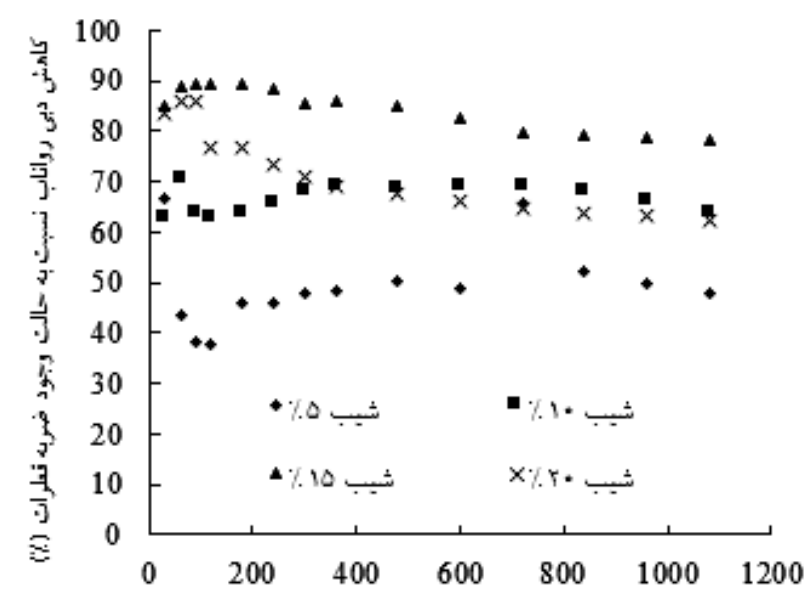

مدت زمان تدأيم روياناب (s)

شكل r. درصد كاهش دبى رواناب در شرايط حذف ضربه قطرات باران نسبت به حالت تأثير مستقيم ضربه قطرات طى زمان رواناب در

$$
\text { شببهاى مورد بررسى }
$$

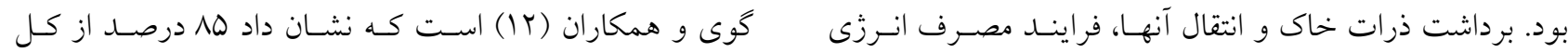

رسوب مربوط به سهم ضربه قطرات باران بود.

حذف ضربه قطرات باران در طول بارندگى، دبى روانـاب

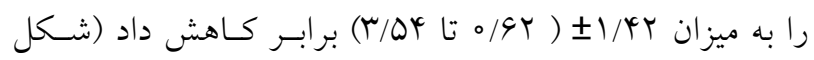

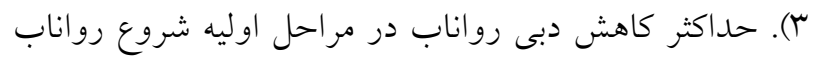

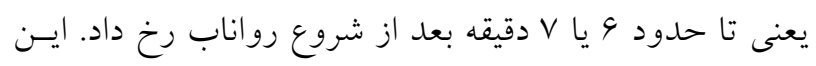

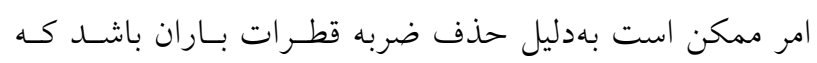

است. هنخامى كه قطرات باران به سطح خاك برخورد مى كنتـد،

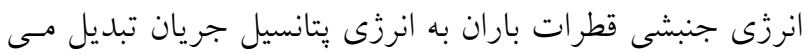

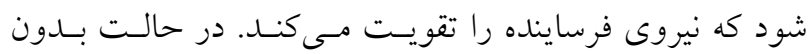
وجود ضربه قطرات باران انرزى جبنشى قطـرات بـاران كـه بــهـ

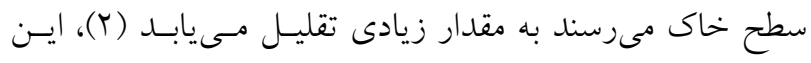

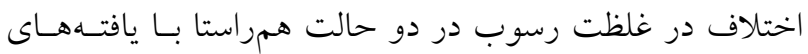




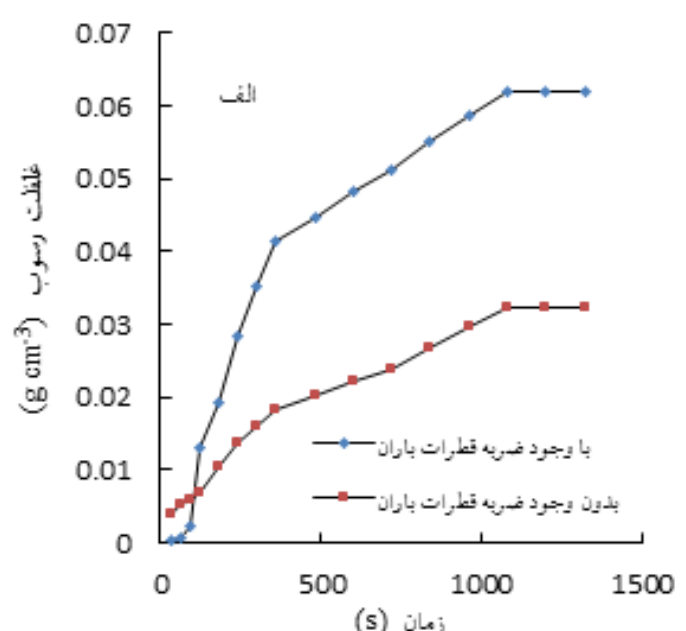

(s) زمان

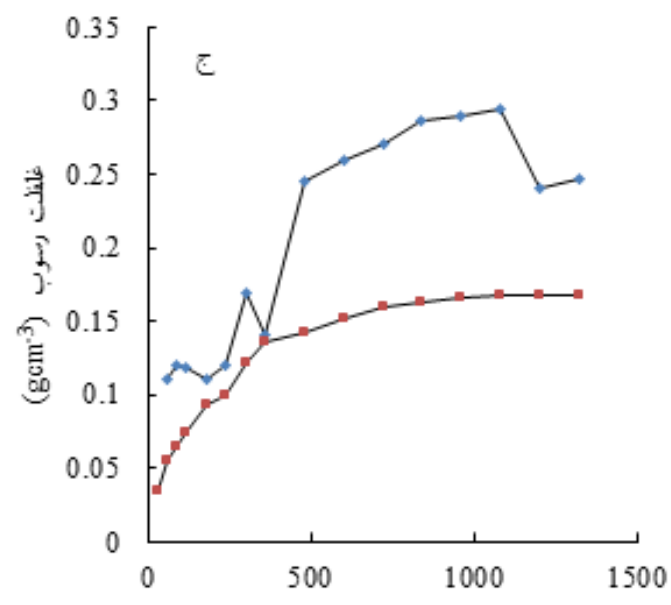

زمان (s)
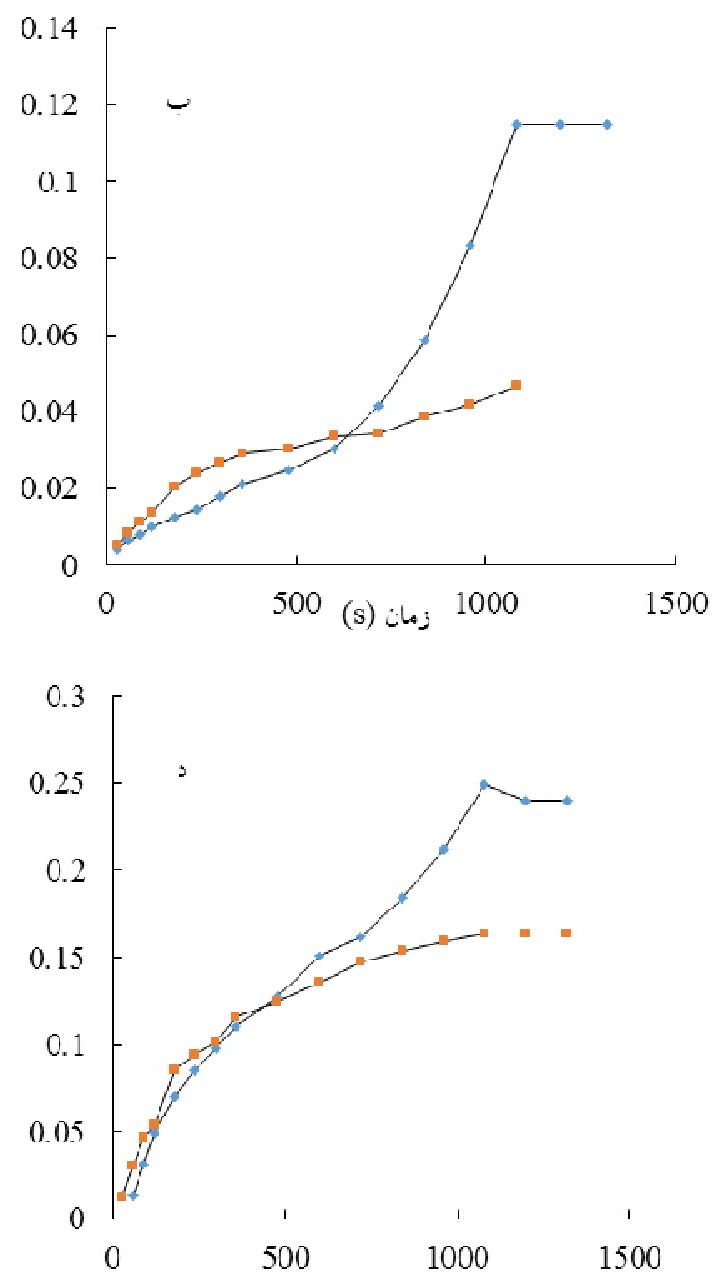

(s) ( ن i j

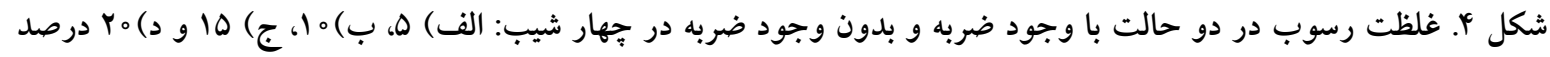
(رنكى در نسخه الكترونيكى)

انرزى جنبشى قطرات باران را كاهش مىدهد و مانع از تشكيل از نظر توليد رواناب است.

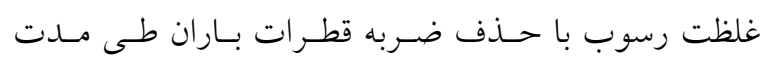

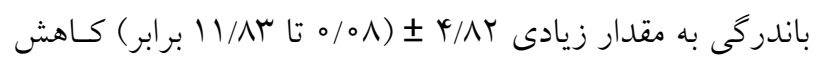

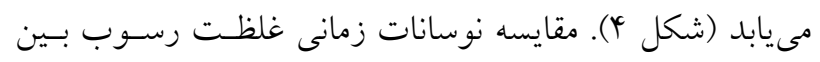

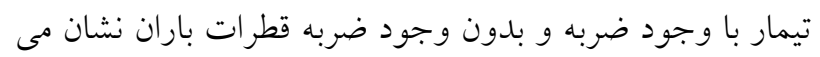
دهد كه برداشت ذرات خاك توسط برخورد قطرات باران مـواد

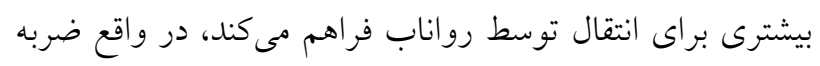

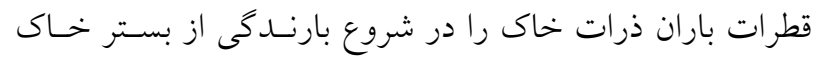

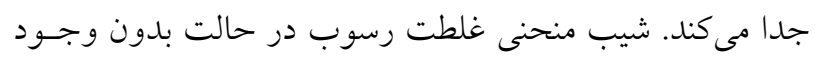

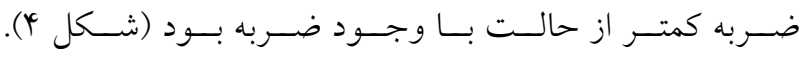

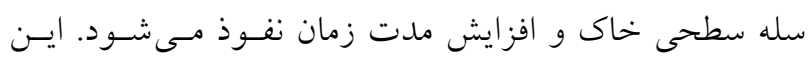

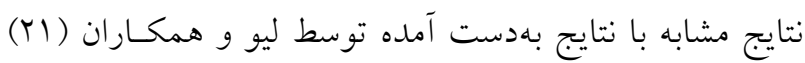
است. تغييرات زمانى درصد كاهش دبى روانـاب بيـانكر ايسن

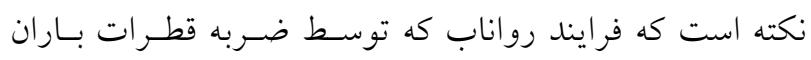

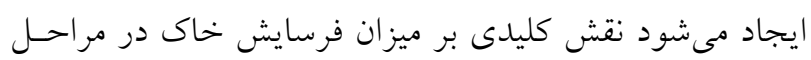

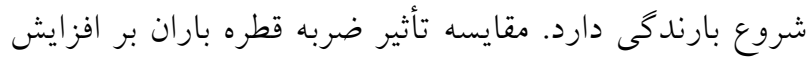

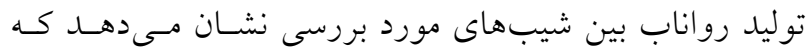

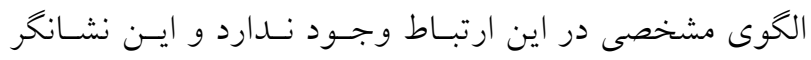
وجود برهم كنش بين دو عامل ضربه قطره باران و شيب سطح 

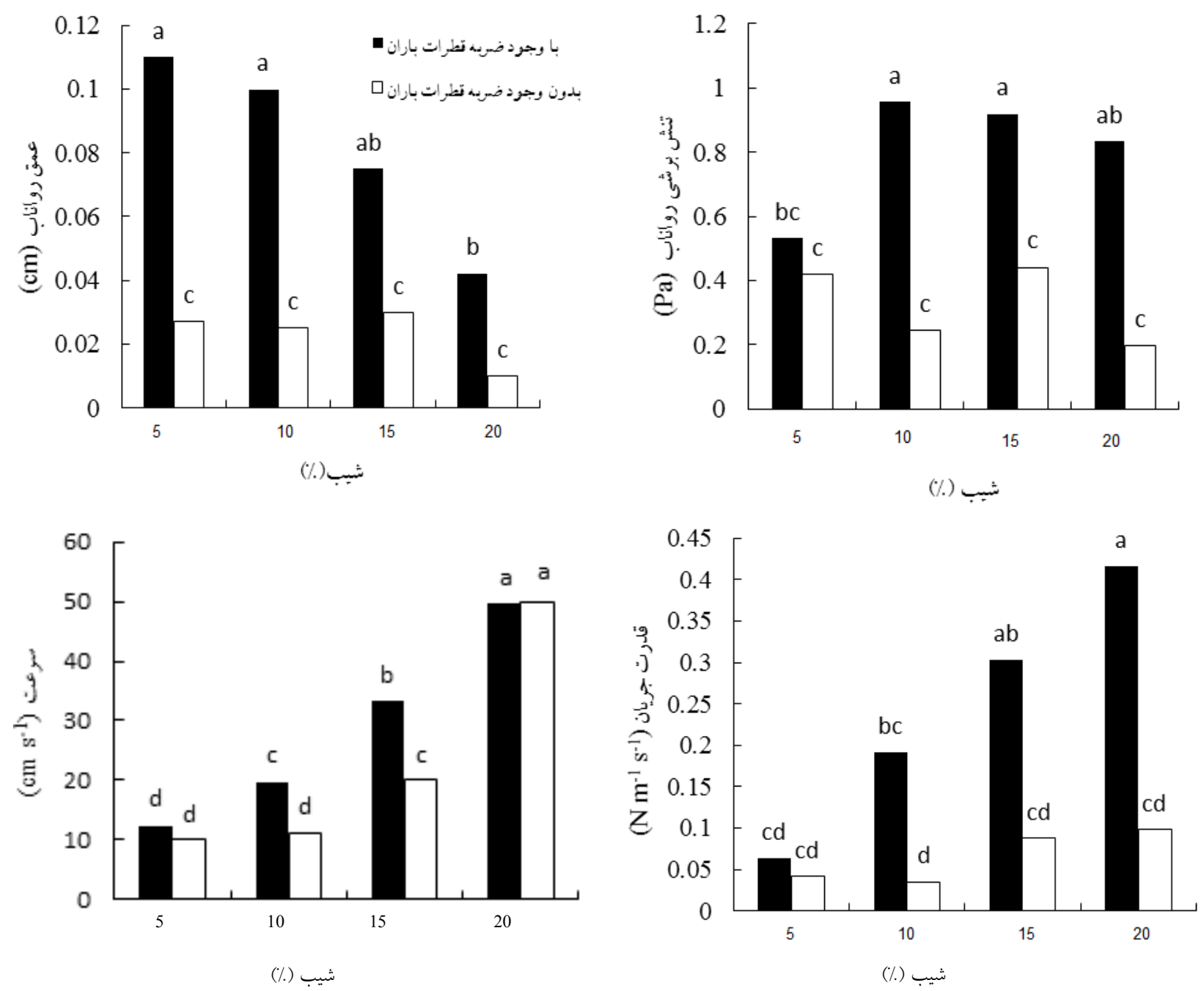

شكل ه. مقايسه عمق رواناب، قدرت جريان و تنش برشى بهترتيب در دو حالت با وجود ضربه و بدون وجود ضربه قطرات باران در جهار

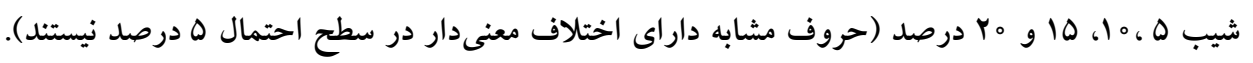

سرعت جريان، عدد رينولدز، ضريب دارسى ويسباخ ، ضـريب

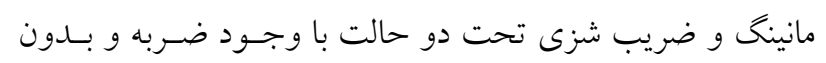

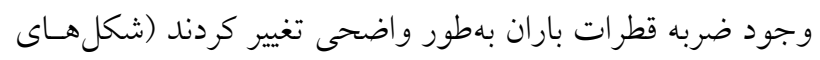

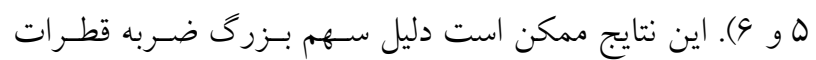

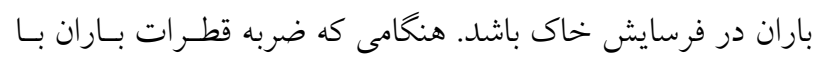

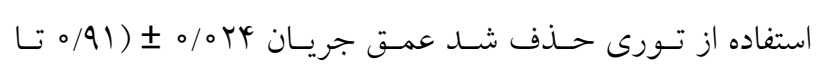

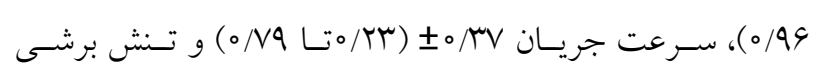
r برابر بمطور معنى دارى كاهش يافت كـه ايـن نتـايج مشـابه نتسايج كزارش شده توسط بيوسلينك و همكاران (Y) است.
بنابراين، استفاده از عمليات حفـاظتى مـؤثر بــراى جلـو گيرى از

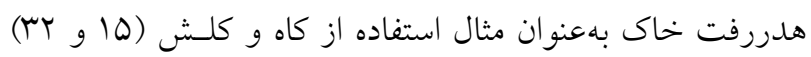

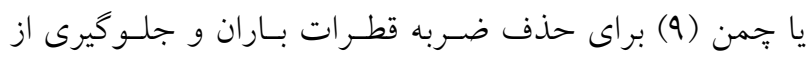
شكسته شدن خاكدانههاى خاى لازم است نقش ضربه قطرات بارن بر ويزگى هــاى هيـدروليكى جريـان تحت تأثير شيب سطح فربه

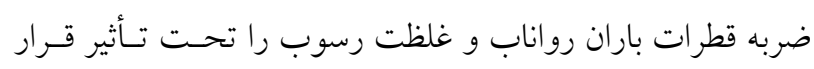

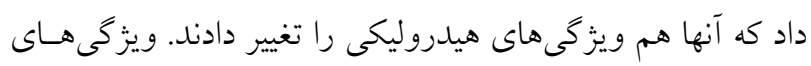

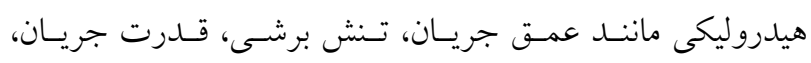



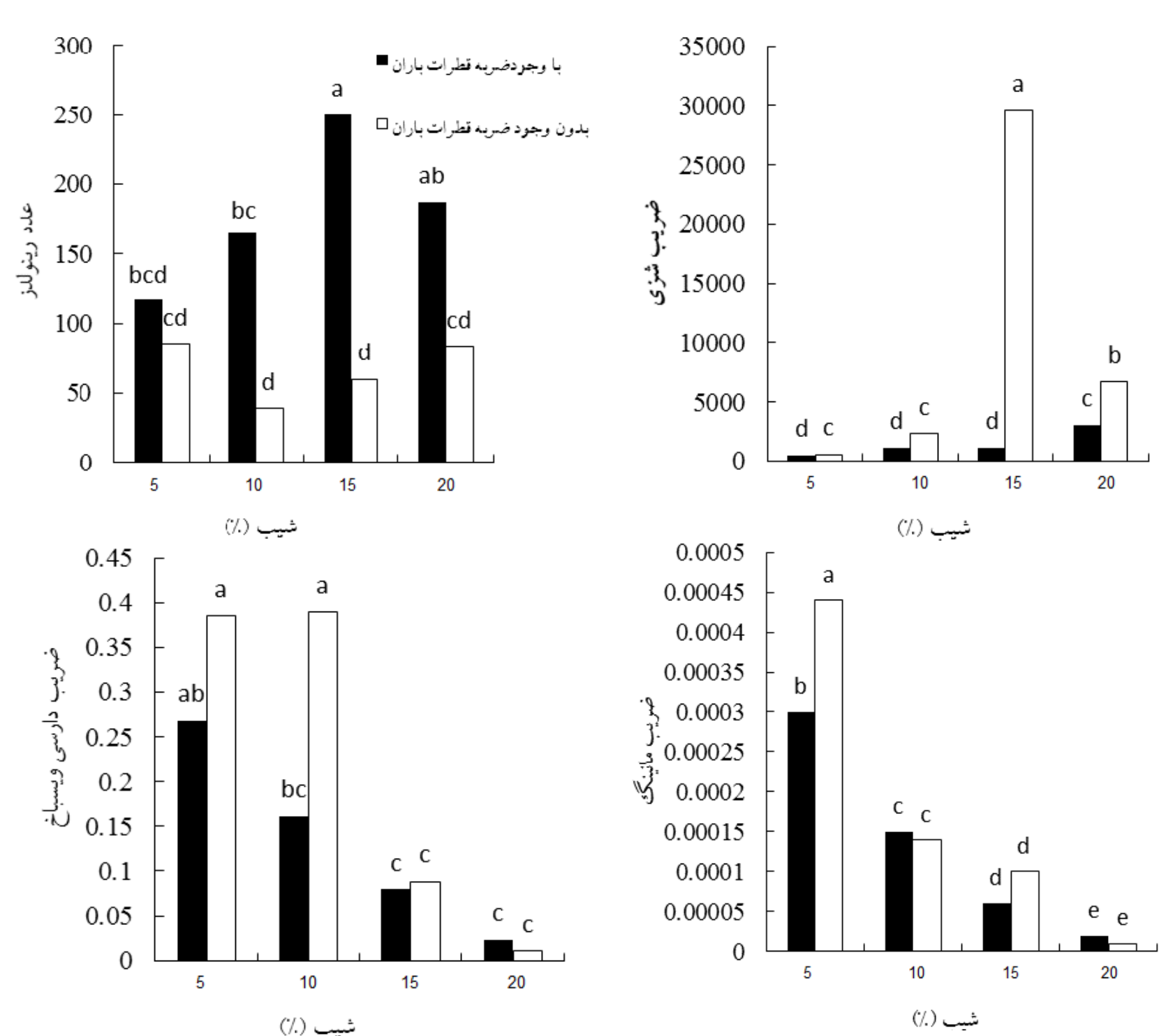

شكل 9. مقايسه عدد رينولدز، ضريب شزى، ضريب دارسى ويسباخ و ضريب مانينيخ در دو حالت با وجود ضربه و بدون وجود ضربه

قطرات باران در جهار شيب ه ، ما، ها و •Y درصد (حروف مشابه داراى اختلاف معنىدار در سطح احتمال يك درصد نيستند).

بنابراين افـزايش در عمـق جريـان و سـرعت جريـان و تلاطـم جريان با ضربه قطرات باران باعث افزايش فرسايش خاى ناشى

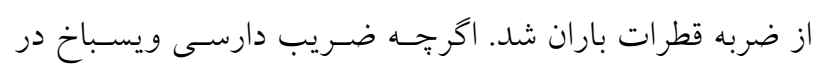
حالت بدون وجود ضربه بيشتر از حالت با وجود ضربه قطرات

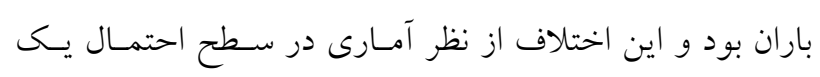
درصسد معنسى دار شـد ( (P<0/01). درحقيقـت در وجـود ضـربه قطرات باران، ذرات تخريب شده توسـط قطـرات بـاران سـطح خاى صافترى ايجاد كرد كه منجر به كاهش تأخير جريان شـد

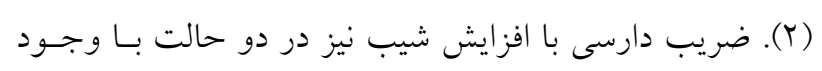

شكل و نشان مىدهد كـه عـدد رينولـــز در شـرايط بـا وجـود ضربه و بلدون وجود ضربه قطرات باران و در جهار شيب مـورد مطالعه مقادير كمتر از هo 4 دارد كـه بيـانكر آرام بــودن جريـان رواناب بود (YV). اكر جهه ضربه قطـرات بـاران رزيــم جريـان را تغيير نمى دهد ولى با حذف ضربه قطرات باران عدد رينولدز در

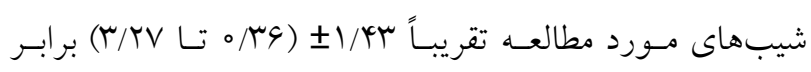
كاهش يافت، كه بيانخر اين حقيقت است كه ضربه قطرات باران تلاطم جريان رواناب را افزايش داد. اثر حــف ضــبه قطـرات باران بر مقدار عدد رينولــز بــا افـزايش شـيب افـزايش يافـت. 
افزايش مىيابد. ميـزان كـاهش دبسى روانـاب بـا حــذف ضـربه قطرات باران با افزايش شيب در طول مدت بارنـــى در زمـان هاى اوليـه شـروع روانـاب بيشـتر بـود ( ( ب/ تـا هم درصــ). همجنين غلظت رسوب در حالت بدون ضربه قطرات بـاران بـه طور معنى دارى كمتر از وجود ضربه قطرات باران بـود ( ^ب تـا

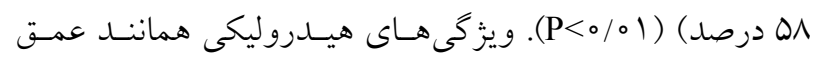
رواناب، سرعت جريان، تنش برشى و قـدرت جريـان بـهــور معنى دارى در حالت بلدون وجود ضربه قطـرات بـاران كمتـر از حالت با وجود ضربه قطرات باران بود (ه>0/P). عدد رينولدز در حالت با وجود ضربه در تمام شيبها بيشتر از حالـت بـدون وجود ضربه بود ( (P<0/01). كه با توجه به نتايج عمق رواناب و سرعت جريان در دو حالت يوشش سطح خاك قابل انتظار بود. ضريب مانينگ و شزى و دارسى ويسباخ در حالت بدون وجود ضربه در سطح احتمال يك درصد بيشتر از وجود ضربه قطرات باران بود، كه اين نتايج با ويز كىهاى هيدروليكى مرتبط همانتـد

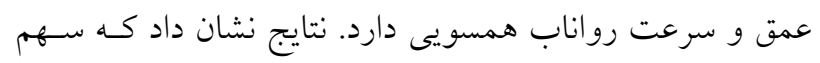
ضربه قطرات باران در ميزان هدررفت خاى در شيارها از طريق تاثير قابل توجهى كه بر ويزّى هاى هيدروليكى مى گذارد، قابـل

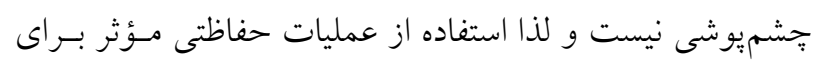

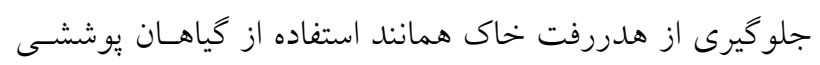
در اراضى شيبدار تحت كشت براى حذف ضربه قطرات باران و جلو گيرى از شكسته شدن خاكدانههاى خاى لازم است.
ضربه و بدون وجود ضربه قطرات باران كاهش يافت. جدول تجزيه واريانش نشان داد كه شيب و ضـربه قطرات باران بر ميزان ضريب مانينخ نيز اثر معنىدارى در سطح احتمال يك درصد داشت. ضريب مانينگ در حالت بدون وجود ضسربه قطرات باران بيشتر از وجود ضربه قطرات باران بود و با افزايش

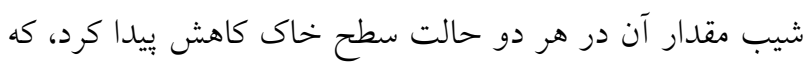
دليل آن بيشتر بودن سرعت جريان در حالت با وجـود ضـربه و نيز در شيبهاى بالا است كه منجر به كاهش ضريب مانينگ در حالت با وجود ضربه در مقايسه با حالت بدون وجـود ضـربه و در شيبهاى بالا مىشود. ضـريب شـزى نيـز در حالـت بـدون وجود ضربه قطرات باران بيشتر از حالت وجود ضـربه قطرات باران در هر جهار شيب مورد مطالعه بود. اين نتايج بيـانخر ايسن حقيقت است كه سرعت جريان يارامتر هيدروليكى كليدى متأثر كننده فرسايش خاى توسط ضربه قطرات باران است.

\section{نتيجه گيرى}

اثر ضربه قطرات باران تقريباً هم درصد هدررفت خاى را شامل

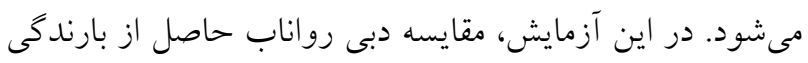

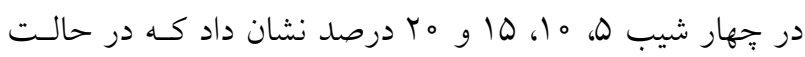
حذف ضربه قطرات بـاران نسـبت بـه حالـت بـا وجــود ضـربه قطرات باران سه تا و V درصد كـاهش يافـت ( (P<0/01). ضـربه قطرات باران نقش كليدى در هدررفت خــاك دارد. بـا افـزايش شيب، برداشت خـاك توسط روانـاب و ضـربه قطـرات بـاران

\section{منابع مورد استفاده}

1. An, J., F. L. Zheng, J. Lu and G. F. Li. 2012. Investigating the role of raindrop impact on hydrodynamic mechanism of soil erosion under simulated rainfall conditions. Journal of Soil Science 177: 517-526.

2. Beuselinck, L., G. Govers, P. B. Hairsine, G. C. Sander and M. Breynaert. 2002. The influence of rainfall on sediment transport by overland flow over areas of net deposition. Journal of Hydrology 257: 145-163.

3. Bryan, R. B. 1990. Knickpoint evolution in rill wash. Catena 17: 111-132.

4. Bryan, R. B. 2001. Soil erodibility and processes of water erosion on hillslope. Geomorphology 32: 385-415.

5. Dunne, T and W. Zhang. 1991. Effects of rainfall, vegetation and microtography on infiltration and runoff. Water Resources Research 27(9): 2271-2285.

6. Ellison, W. D. 1944. Studies of raindro erosion. Transactions of the ASAE, an International Journal Published by the American Society of Agricultural Engineers 25: 181-182.

7. Ellison, W. D. 1945. Some effects of raindrops and surface flow on soil erosion and infiltration. Transactions of the American Geophysical Union 26: 415-429. 
8. Emmett, W. W. 1970. The hydraulics of overland flow on hillslopes. Geological Survey Professional $662-664$.

9. Fullen, M. A. 1998. Effects of grass ley set-aside on runoff, erosion and organic matter levels in sandy soils in East Shropshire, UK. Soil Tillage Research 46: 41-49.

10. Gao, B., M. T. Walter, T. S. Steenhuis, J. Y. Parlange, B. K. Richards, W. L. Hogarth, C. W. Rose and G. Sander. 2005. Investigating raindrop effects on the transport of sediment and non-sorbed chemicals from soil to surface runoff. Journal of Hydrology 308: 313-320.

11. Gilley, J. E., W. J. Elliot, J. M. Laflen and J. R. Simanton. 1993. Critical shear stress and critical flow rates for initiation of rilling. Journal of Hydrology 142: 251-271.

12. Guy, B. T., R. P. Rudra, W. T. Dickenson and T. M, Sohrabi. 2009. Empirical model for calculating sedimenttransport capacity in shallow overland flows: model development. Biosystems Engineering 103: 105-115

13. Haiou, S., Z. Fenli, W. Leilei, L. Jia and Y. Jiang. 2015. An experimental study of rill erosion and morphology. Geomorphology 231: 193-201.

14. Hung, Y., X. Chen, B. Luo, L. Ding and C. Gong. 2015. An experimental study of rill sediment delivery in purple soil, using the volume-replacement method. Peer Journal 1220.

15. Jin, K., W. M. Cornelis, D. Gabriels, M. Baert, H. J. Wu, W. Schiettecatte, D. X. Cai, S. De Neve, J. Y. Jin and D. Hofman. 2009. Residue cover and rainfall intensity effects on runoff soil organic carbon losses. Catena 78: 81-86.

16. Kemper, W. D and R. C. Rosenau. 1986. Aggregate stability and size distribution. In: Methods of Soil Analysis, Part I. Physical and Mineralogical Methods (2nd Edition) Agronomy Monography, No. 9. PP. 425-442.

17. Klute, A. 1996. Methods of Soil Analysis, Part I: Physical and Mineralogical Methods. SSSA Book Series No.5. Madison.

18. Lei, T. W., M. A. Nearing, K. Haghighi and V. F. Bralts. 2001. Rill erosion and morphological evolution: A simulation model. Water Resources Research 34(11): 3157-3168.

19. Li, G. L., F. Q. Wu, X. M. Pang and X. F. Zhao. 2008. Relationship between sediment transport with surface rainfall and runoff energies on sloping. Advances in Water Resources 19(6): 868-874. (In Chinese).

20. Li, Z. W., G. H. Zhang, R. Geng and H. Wang. 2015. Rill erodibility as influenced by soil and land use in a small watershed of the Loess Plateau, China. Biosystems Engineering 129(1): 248-257.

21. Lu, J., F. Zheng, G. Li, F. Bian and J. An. 2016. The effects of raindrop impact and runoff detachment on hillslope soil erosion and soil aggregate loss in the Mollisol region of Northeast China. Soil \& Tillage Research 161: 79-85.

22. Nearing, M. A., L. D. Norton, D. A. Bulgakov, L. T. Larionov and K. M. Dontsova. 1997. Hydraulics and erosion in eroding rills. Water Resources Research 33: 865-876.

23. Reichert, J. M. and L. D. Norton. 2013. Rill and interrill erodibility and sediment characteristics of clayey Australian Vertosols and a Ferrosol. Soil Research 51: 1-9.

24. Romero, C. C., L. Stroosnijder and G. A. Baigorria. 2007. Interrill and rill erodibility in the northern Andean Highlands. Catena 70: 105-113.

25. Shapiro, S. S. and M .B. Wilk. 1965. An analysis of variance test for normality (complete samples). Biometrika 52(3-4): 591-611.

26. Vaezi, A. R. and F. Besharat. 2015. Rainfall during Events on Runoff and Soil Loss under Simulated Rainfalls. Iranian Journal of Watershed Management Science and Engineering 9(29): 9-18

27. Wenying, P., Z. Zhuodong and K. Zhang. 2015. Hydrodynamic characteristics of rill flow on steep slopes. Hydrological Process Journal 29: 3677-3686.

28. Wu, P. T. and P. H. Zhou. 1994. The effects of raindrop splash on the sheet flow hydraulic friction factor. Journal of Soil Erosion and Soil Water Conservation 8(2): 39-42. (In Chinese).

29. Xu, Z., J. E. Gao, C. H. Zhao and H. Han. 2010. Effects of raindrop impact on runoff and sediment transport of the slope. Journal of Soil and Water Conservation 24(6): 20-33.

30.Zartj, A. S., A. Klik and C. Huang. 2001. Soil detachment and transport processes from interrill and rill areas. Chemical and Earth Science 26: 25-36.

31. Zhang, G. H., R. I. Shen, L. O. Chang, T. G. Rong, Y. G. Cao and X. C. Zhang. 2010. Effects of sediment load on hydraulics of overland flow on steep slopes. Earth Surface Processes and Landforms 35: 1811-1819.

32. Zhang, G. H., R. T. Luo, Y. Cao, R. C. Shen and X. C. Zhang. 2010. Correction factor to dyemeasured flow velocity under varying water and sediment discharges. Journal of Hydrology 389: 205-213. 


\title{
Effect of Raindrops Impact on Hydraulic Properties of the Rill Flow under Slope Gradients
}

\author{
N. Sadeghian ${ }^{1}$, A. Vaezi ${ }^{1 *}$ and A. Majnooni Heris ${ }^{2}$
}

(Received: January 3-2018; Accepted: May 19-2018)

\begin{abstract}
Few studies have been done regarding the role of the raindrop in the hydrodinamic mechanism of soil erosion. In this study, rainfall simulation experiments were conducted to evaluate the role of raindrop in runoff discharge, sediment concentration and hydraulic properties of flow under four slope gradients $(5,10,15$ and 20\%) in a clay soil using a 90 $\mathrm{mm} . \mathrm{h}^{-1}$ rainfall intensity to reach the steady state flow. Soil sample was packed into the erosion flume with $0.3 \mathrm{~m} \times 0.4 \mathrm{~m}$ $\times 4 \mathrm{~m}$ in dimensions and tested under two soil surface conditions: one with raindrop impact and one without raindrop impact. The results showed that runoff discharge, sediment concentration, flow depth, shear stress, stream power, Reynolds number and runoff velocity under without raindrop impact condition were significantly lower than those in the condition with the raindrop impact with a factor of 0.62 to $3.54,0.08$ to $11.83,0.91$ to $0.96,0.26$ to $3.25,0.52$ to 4.45, and 0.36 to $3.27,0.23$ to 0.79 times, respectively; on the other hand, the Darcy Wysbach, Chezy and Manning coefficients were increased significantly under without raindrop impact $(\mathrm{P}<0.01)$. Flow velocity was the key hydraulic parameter strongly affecting the hydraulic properties. These findings indicated the importance of raindrop impact in the detachment rate of soil particles through the change of the hydraulic characteristics. This study also revealed the key role of raindrop impact on the runoff hydraulic characteristics, as well as particle detachments rate in rills. Information about the role of raindrop impact is a substantial step in modeling the rill erosion. Therefore, elimination of raindrops impact, especially in the steep slopes, with the conservation of natural vegetation cover can sufficiently prevent runoff production as well as the particle detachment rate.
\end{abstract}

Keywords: Runoff discharge, Sediment concentration, Shear stress, Soil surface, Stream power.

1- Department of Soil Science, Faculty of Agriculture, University of Zanjan, Zanjan, Iran.

2- Department of Water Science Engineering, Faculty of Agriculture, University of Tabriz, Tabriz, Iran.

*: Corresponding author, Email: vaezi.alireza@gmail.com 